\title{
Argumentasi Fatwa Dar Al-Ifta Al-Mashriyyah tentang Shalat Jum'at dalam Jaringan (Daring)
}

\author{
Fahmi Hasan Nugroho ${ }^{1}{ }^{*}$, Muhammad Syarif Hidayat ${ }^{2}$ \\ ${ }^{1}$ Department of Sharia and Law, UIN Sunan Gunung Djati Bandung, Indonesia \\ 2Department of Sharia and Law, Universitas Islam Negeri Wali Songo, Indonesia \\ *Corresponding Author E-mail: fahmihasan91@uinsgd.ac.id
}

\begin{abstract}
This study analyzes the fatwa arguments from Dar al-Ifta al-Mashriyyah regarding Friday prayers which are carried out over the network, either through radio or via online video calls. This study found that Dar al-Ifta al-Mashriyyah stated that prayers carried out through radio or internet networks were not valid because they did not meet the legal requirements of Friday prayers, which were carried out in congregation and the imam and congregation were in the same place. The strongest arguments put forward by Dar al-Ifta al-Mashriyyah are the three arguments for ijma ', namely ijma' that khutbah is a valid requirementfor Friday prayers, ijma 'that Friday prayers must be carried out in congregation, and ijma' that Friday prayers' at can only be done in the mosque. Apart from the argument of ijma ', Dar al-Ifta al-Mashriyyah also argued with the Sunnah of the Prophet in the implementation of Friday prayers, and a number of other arguments. This research is a normative legal research with a legal clinical approach (istinbath $a l-h u k m$ ). The data reviewed in this study were five fatwas of Dar al-Ifta al-Mashriyyah which were released between 1950 and 2020.
\end{abstract}

Keywords: Fatwa, Friday Prayer, Online

\begin{abstract}
ABSTRAK
Penelitian ini menganalisis argumentasi fatwa dari Dar al-Ifta al-Mashriyyah terkait shalat Jum'at yang dilaksanakan melalui jaringan, baik bermakmum melalui radio maupun melalui panggilan video online. Penelitian ini menemukan bahwa Dar al-Ifta al-Mashriyyah menyatakan bahwa shalat yang dilakukan melalui jaringan radio ataupun internet tidak sah dilaksanakan karena tidak memenuhi syarat sah shalat jum'at yaitu dilakukan secara berjamaah serta imam dan makmum berada di tempat yang sama. Argumentasi terkuat yang diajukan oleh Dar al-Ifta al-Mashriyyah adalah tiga argumentasi ijma', yaitu ijma' bahwa khutbah adalah syarat sah shalat Jum'at, ijma' bahwa shalat Jum'at harus dilaksanakan secara berjamaah, dan ijma' bahwa shalat Jum'at hanya dapat dilaksanakan di masjid. Selain argumentasi ijma', Dar al-Ifta al-Mashriyyah juga berargumentasi dengan sunnah Rasulullah dalam pelaksanaan shalat Jum'at dan sejumlah argumentasi lain. Penelitian ini merupakan penelitian hukum normatif dengan pendekatan klinis hukum (istinbath al$h u k m)$. Data yang dikaji dalam penelitian ini adalah lima buah fatwa Dar al-Ifta al-Mashriyyah yang dirilis antara tahun 1950 hingga tahun 2020.
\end{abstract}

Kata Kunci: Fatwa, Shalat Jum'at, Online

\section{PENDAHULUAN}

Pada pertengahan bulan Maret 2020 terjadi pembatasan kegiatan keagamaan di masjid secara serentak di berbagai negara akibatmerebaknya virus Covid-19yang telah menyebar ke berbagai negara. Pembatasan kegiatan keagamaan tersebut muncul baik melalui fatwa dari otoritas keagamaan setempat maupun melalui kebijakan dari pemerintah. Adanya pembatasan kegiatan keagamaan di masjid tersebut

* Copyright (c) 2021 Fahmi Hasan Nugroho et.al

This work is licensed under a Creative Commons Attribution-ShareAlike 4.0 International License. 
menjadikan pelaksanaan kegiatan keagamaan mengalami perubahan. Kegiatan-kegiatan keagamaan non ibadah seperti pengajian dan peringatan hari besar Islam dilaksanakan secara online, sedangkan kegiatan keagamaanyang berbentuk ibadah seperti shalat wajib berjamaah, shalatjum'at, shal at terawih dibatasi, bahkan haji dan umrah pun ditiadakan. Sebagimana pelaksanaan Misa yang dilakukan secara online oleh beberapagereja saat masa pandemi, muncul juga ide untuk melaksanakan shal at berjamaah secara online, baik shalat wajiblima waktu ataupun shalatJum'at secara online (A. Wahid, 2020).

Shalat wajib berjamaah yang dilakukan secara online dilakukan dengan cara makmum mengikuti imam yang disiarkan melalui pengeras suara ataupun video. Dalam hal ini Hishshah bint Abdul Aziz alSudais merinci permasalahan ini ke dalam beberapa kategori: 1) Jika makmum mengikuti imam melalui pengeras suara atau video televisi dan keduanya berada di tempat yang sama dan ada hajah (kebutuhan) untuk melaksanakan dengan cara itu—seperti di masjidil haram yangluas, jamaah yang banyak, banyak lantai dan banyaksekat dinding — maka para ulama sepakat bahwa hal ini sah dilakukan. 2) Jika imam dan makmum berada di wilayah yang sama, namun tidak ada hajah untuk melakukan hal tersebut-seperti orang yangtinggal di hotel dan pertokoan di sekitaran masjid — makaitu tidak sah dilakukan. 3) Jika imam dan makmum berada di wilayah yang berbeda namun ada hajah untuk melaksanakannya-seperti adanya pembatasan sosial dan penutupan masjid di masa wabah Covid 19-maka menurutnya itu sah dilaksanakan (Al-Sudais, 2021).

Argumentasi Binti Abdul Aziz al-Sudais di atas didasari atas adanya hajah atau kebutuhan karena terbatasnya pelaksanaan shalatjamaah di masa Covid. Ia juga berargu men bahwa batasan yang disepakati dalam berjamaah adalah kemampuan mengetahui dan mengikuti gerakan imam, dan pelaksanaan melalui video masih memungkinkan bagi makmum untuk mengikuti gerakan imam, atas dasar ini ia mensyaratkan bahwa harus ada kesamaan waktu antara makmum danimam (Al-Sudais, 2021).

Dalam artikel diatas, Binti Abdul Aziz hanya membahas mengenai shalatberjamaah secara online, namun tidak membahas mengenai shalat Jum'at yang dilakukan secara online. Perbedaan antara keduanya jelas terletak pada adanya khutbah sebagai syarat sah dari pelaksanaan shalat Jum'at. Shalat Jum'at online ini dilakukan dengan cara imam (dan/sekaligus) khatib serta makmum yang berada di tempatyang berbeda namun saling terhubungmelalui jaringan, baik radio a taupunjaringan internet

Selama tahun 2020, pelaksanaan shalat Jum'at dengan tata caraini telah dilaksanakan di sejumlah wilayah seperti komunitas Muslim di Finlandia dan komunitas Muslim di Princeton University (Kenshanahan, 2021). Adanya pelaksanaan shalat Jum'at secara online tersebut direspon di Indonesia dengan munculnya salah satu artikel yang dirilis oleh Redaksi NU Online mengenai kebolehan pelaksanaan shalat Jum'at dengan cara tersebut (Kurniawan, 2020). Respon yang sama juga muncul dari Wawan Gunawan Abdul Wahid yang bahkan tidak hanya menulis sebuah artikel namun juga melaksanakan shalatJum'at secara online melalui mediaZoom sejak 29 Mei 2020 (Siregar,2021).

Dalam tulisannya, Wahid mengajukan dua argumentasi bagi keputusannya melaksanakan shalat Jum'at melalui media online itu. Argumentasi pertama adalah dengan memposisikan rumah sebagai masjid atas dasar hadis Rasulullah yang menyatakan bahwa di anta ra keistimewaan umat Islam adalah tanah manapun suci dan dapat digunakan untuk melaksanakan shalat. Argumentasi kedua adalah dengan menggunakan qiyas terhadap akad nikah yang dapat dilaksanakan secara online. Wahid juga mengutip sejumlah argumentasi bagi kebolehan shalat Jum'at dari Ahmad b. Muhammad b. al-Shiddiq al-Gumari dalam bukunya al-Iqna' bi Shihhat Shalat al-Jum'ah fi al-Manzil Khalf al-Midzya' yang menyatakan kebolehan shalat dibelakang radio (W. G.A. Wahid, 2020).

Berbeda dengan pendapat di atas, Dar al-Ifta al-Mashriyyah, lembaga fatwa Republik Arab Mesir menyatakan bahwa pelaksanaan shalatJum'at melalui media online tidak sah untuk dilaksanakan. Fatwa 
tersebut dilandasi atassejumlah argumen, yaitu:1) pelaksanaan semacam itu tidak dapat disebut sebagai suatu "perkumpulan" (ijtima') padahal shalat jum'at mensyaratkan adanya ijtima', 2) pelaksanaan semacam inibertentangan dengan kesepakatan para ulamayang mensyaratkan adanya ketersambungan shaf shalat dan tempat yang sama antara imam dan makmum, 3) tidak hadirnya makmum di tempat di mana khutbah Jum'at dilaksanakan ('Allam, 2020a, hal. 193-203).

Fatwa di atas adalah fatwa dari Syauqi 'Allam, Mufti Negara Republik Arab Mesir, yang awalnya dirilismelalui website Dar al-Ifta al-Mashriyyah pada tanggal 30 Maret 2020 dengan judul Shalatal-Jum'ah Khalfal-Tilfaz ('Allam,2020b).Pada Agustus 2020, Dar al-Ifta al-Mashriyyah kemudian merilis satu buku khusus yang mengumpulkan seluruh fatwa yang berkaitan dengan virus Covid-19 dengan judul Fatawa al-Nawazil: Waba Corona (Covid-19) dan memasukkan fatwa tersebut ke dalam salah satu fatwa di buku itu. Dalam fatwatersebut Syauqi 'Allam juga mengutip sejumlah fatwa yang dirilis oleh para mufti Dar alIfta al-Mashriyyah pada masa-masa terdahuluyang masih berkaitan dengan halini.

Setelah melakukan penelusuran terhadap silsilah fatwa Dar al-Ifta al-Mashriyyah penulis menemukan setidaknya ada empat fatwa yang terkait dengan hal ini selain dari fatwa Syauqi 'Allam di atas, yaitu fatwa yang dirilis oleh Hasanayn Makhluf, Hasan Ma'mun, Muhammad Khathir dan Jadal-Haqq. Dalam lima fatwa itu diketahui bahwa Dar al-Ifta al-Mashriyyah konsisten menyatakan bahwa shalat jum'at dalam jaringan tidak sah untuk dilakukan.

Penulis menilai bahwa penelitian terhadap argumentasi Dar al-Ifta al-Mashriyyah terkait hal ini menarik untuk dilakukan karena Dar al-Ifta al-Mashriyyah telah merespon permasalahan ini sejak tahun 1950, yaitu fatwa yang dirilis oleh Hasanayn Makhluf. Terlebih lagi, sejauh penelusuran penulis belum ditemukan adanya penelitian yang membahas mengenai shalat jum'at online secara umum ataupun penelitian yang secara khusus membahas fatwa Dar al-Ifta al-Mashriyyah dalam masalah ini. Maka, penelitian ini tepat untuk dilaksanakan dengan harapan dapat menjadi bahan pertimbangan bagi para peneliti, cendekiawan muslim ataupun masyarakat muslim secara umum mengenai keabsahan shalat yang dilakukan secara online ini.

\section{METODOLOGI PENELITIAN}

Penelitian ini adalah penelitian kualitatif dengan bentuk kajian pustaka. Penelitian ini merupakan penelitian-yang oleh Faisar Ananda Afra disebut dengan penelitian-Klinis Hukum, atau penelitian Istinbath al-Ahkam, yaitu penelitianyang dilakukan dengan melihat proses hukum yang terjadi sehingga tercapainyasuatu pendapat hukum (Arfa, 2010, hal.59-61). Penelitianini termasuk ke dalam salah satu jenis penelitian hukum normatif.

Data primer yang digunakan di dalam penelitian ini adalah lima fatwa Dar al-Ifta al-Mashriyyah yang berkaitan dengan shalat di dalam jaringan, empat fatwa mengenai shalat Jum'at dengan khutbah atau imam melalui radio dan satu fatwa mengenai shalat Jum'at melalui video call. Sedangkan data sekunder adalah sejumlah buku dan jurnal yang berkaitan dengan tema penelitian. Data yang didapat kemudian dianalisis menggunakan pendekatan ilmu ushul fiqh.

\section{HASIL DAN PEMBAHASAN}

\section{Fatwa Dar al-Ifta al-Mashriyyah tentang Shalat Jum'at dalam Jaringan}

Sebagaimana yang dijelaskan di atas bahwa shalat Jum'at dalam jaringan atau shalat online dilakukan dengan cara imam (dan/sekaligus) khatib serta makmum yang berada di tempatyang berbeda 
namun saling terhubung melalui video call dalam jaringan internet. Hal yang serupa telah terjadi sejak dahulu, meski media yang digunakan bukanlah media internet melainkan radio atau pengeras suara masjid. Namun baik shalatJum'at online ini dan shalatJum'at melalui radio atau pengeras suara keduanya memiliki kesamaan yaitu adanya jarak yang jauh antara imam (dan/sekaligus) khatib serta m akmum karena mereka berada ditempatyang berbeda.

Pembahasan mengenai pelaksanaan shalat Jum'at dengan tata cara seperti ini telah dibahas oleh para mufti di Dar al-Ifta al-Mashriyyah setidaknya sejak tahun 1950. Pada 1 Februari 1950, Hasanayn Makhluf (w. 1410 H/1990 M), Mufti Negara Mesir yang ke 8 (1946-1950, dan ke 10 tahun 1952-1954) telah merilis fatwa yang menjawab sebuah pertanyaan mengenai suatu masjid yang telah melaksanakan shalat jum'at tanpa ada imam dan khatib karena mengikuti siaran shalat Ju m'at melalui Radio. Dalam fatwa tersebutHasanayn Makhlufmenyatakan bahwa shalat masjid tersebutyang dilakukan dengan cara sepertiitu tidaklah sah (Makhluf, 2010, hal. 26).

Kemudian pada 8 September 1955, Hasan Ma'mun (w. 1393 H/1973 M), Mufti Negara Mesiryang ke 11 (1955-1964) merilisfatwa yang serupa sebagai respon dari pertanyaan mengenai shalat Jum'atyang khutbahnya berasal dari radio meski shalatnya diimami secara langsung oleh seorang Imam. Hasan Ma'mun pun menjawab dengan jawaban yang sama yaitu shalat dengan tata cara seperti itu tidak sah dilakukan (Ma'mun, 2010, hal. 29-30).

Pada 20 Juni 1976 Muhammad Khathir Muhammad al-Syaikh (w. 1390 H/2004 M), Mufti Negara Mesir yang ke 13 (1970-1978) merilis fatwa yang merespon pertanyaan mengenai shalat Jum'at yang khutbah dan imamnya dilakukan melalui radio karena orang yang biasa menjadi imam sekaligus khatib tidak hadir hingga waktu adzan sehingga jamaah berinisiatif untuk mengikuti shal at jum'at yangdisiarkan melalui radio. Dalam kasus ini, Muhammad Khathir memfatwakan hal yang sama dengan fatwa yang sebelumnya bahwa shalat dengan tata carainitidak sah dilakukan (Al-Syaykh, 2010, hal. 57-58).

Pada 16 Januari 1979, Jad al-Haqq 'Ali Jad al-Haqq (w. 1416 H/1996 M), Mufti Negara Mesir yang ke 14 (1978-1982) merespon sebuah pertanyaan mengenai seseorangyang tidak mampu pergi ke masjid dan ia hendak mengikuti shalat Jum'at dari rumah dengan menyimak khutbah dan bermakmum melalui suara yang dipancarkan melalui pengeras suara masjid. Dalam fatwanya Jad al-Haqq menjelaskan dua hal, yang pertama adalah bahwa syarat shalat Jum'at harusdilaksanakan di masjid (dan tidak bisa dilakukan di rumah), dan yang kedua menjelaskan tentang batasan jarak maksimal bolehnya shalat berjamaah menurut empat mazhab. Atas dasar itu ia menyatakan bahwa mengikuti shalat Jum'at di rumah dengan mengikuti suara yang dipancarkan melalui pengeras suara masjid tidaklah sah, namun untuk shalat berjamaah dari luar masjid masih diperbolehkan meski terhalang oleh sungai atau jalan sebagaimana pendapatmazhab yang ia kutip dalam fatwanya (Al-Haqq, 1979).

Sebagaimana fatwa Hasanayn Makhluf yang pertama, fatwa-fatwa yang dirilis setelahnya membahas mengenai shalat yang dilakukan dengan imam dan khatib (atau salah satunya) melalui suara saja, baikyang dipancarkan melalui radio ataupun melalui pengerassuara masjid. Berbeda dengan fatwa yang dirilis oleh Syauqi 'Allam pada Maret2020yang merespon mengenai shalatJum'at melalui video call sebagaimana pembelajaran online. Dua kasus tersebut sekilas memang berbeda, karena dalam fatwafatwa sebelumnya makmum hanya mengikuti suara imam tanpa melihatnya, sedangkan dalam fatwa Syauqi 'Allam makmum tidak hanya mengikuti suara imam namun juga bisa melihatgerakan imam, dan salah satu ukuran yang dibahas oleh para ulama mengenai sah atau tidaknya bermakmumadalah ketika makmum bisa mengetahui gerakan imam baik karena mendengar suara imam ataupun dengan melihat gerakannya. 
Meski dua kasus itu memiliki perbedaan dalam hal media dan hal yang diikuti oleh makmum, namun keduanya memiliki kesamaan dalam hal terpisahnya jarak a ntara imam (dan/sekaligus) khatib serta makmum karena tempat yang berbeda. Atas dasar itulah Syauqi ‘Allam di dalam fatwanya menyatakan bahwa hal tersebut dilarang dengan sejumlah argumentasi yang akan dibahas dalam bagian berikutnya.

Fatwa Syauqi 'Allam ini dirilis pertamakali melalui website Dar al-Ifta al-Mashriyyah dengan judul "hukm al-shalat khalfa al-tilfaz" pada 30 Maret 2020, bulan yang sama ketika Syauqi 'Allam merilis sejumlah fatwa mengenai virus Covid-19 sebagai respon dari mulai ditemukannya kasus Covid-19 di Mesir (Rusyana etal., 2020). Fatwaini merespon pertanyaanyang diajukan oleh Majelis Spiritual Muslim Rusia yang mana para mufti di Rusia sendiri memiliki perbedaan pendapat mengenai hal ini sehingga mereka perlu untuk meminta opini dan fatwa dari Dar al-Ifta al-Mashriyyah ('Allam, 2020b). Fatwa ini kemudian dirilis ulang di dalam buku kumpulan fatwa tentang covid-19 dengan judul " $\mathrm{hu} k \mathrm{~km}$ al-shalat khalfa al-midzya"' ('Allam, 2020a).

Selain fatwa di atas, terdapat satu fatwa lain yang dirilis oleh 'Allam Nashr (w. 1386 H/1966 M), mufti Negara Mesir yang ke 9 (1950-1052), yang dirilis pada tahun 1951 dan disinggung oleh Syauqi 'Allam dalam fatwanya, namun teks fatwa tersebut tidak dapat ditemukan baik di dalam website Dar alIfta al-Mashriyyah maupun di dalam buku ensiklopedi fatwa Dar al-Ifta al-Mashriyyah. Namun meski begitu, di dalam fatwanya Syauqi 'Allam menyatakan bahwa fatwayang ia ril is menyatakan hal yang sama dengan fatwa-fatwa Daral-Ifta al-Mashriyyah yang lain, termasuk fatwadari 'Allam Nashrini.

\section{Tahapan dan Rujukan Fatwa Dar al-Ifta al-Mashriyyah}

Salah satu metode yang digunakan dalam berfatwa di Dar al-Ifta al-Mashriyyah dikenal dengan marahil al-ifta (tahapan berfatwa) yang merupakan aturan baku tentang proses yang harus dilakukan dalam perumusan sebuah fatwa. Empat tahapan tersebut adalah: fase tashwir, takyif, hukm, dan ifta ('Allam, 2020c, hal. 29-36).

Fase pertama adalah fase tashwir atau fase penggambaran. Tashwir serupa dengan tashawwur di dalam ilmu Mantik karena berasal dariakar kata yang sama. Dalam ilmu Mantiq sendiri tashawwur didefinisikan sebagai pengetahuan/gambaran terhadap sesuatu yang tidak disertai penghukuman apapun terhadap sesuatu itu (Nuruddin, 2019, hal. 47). Dalam fase ini seorang faqih mendalami permasalahan yang hendak dihadapi dengan sungguh-sungguh sehingga ia mampu mengetahui segala unsur yang berkaitan dengan masalah tersebut, unsur-unsur yang mempengaruhinya, dampak yang ditimbulkan oleh unsur tersebut dan cara mengatasi dampak yang muncul darinya.

Fase selanjutnya adalah fase takyif atau fasepengembalian masalah ke dalam bab induknya. Dalam bahasa lain, takyifdisebut juga dengan adaptasi fiqih (Khairuldin etal., 2020).Setelahgambaran mengenai permasalahan yang dibahas telah didapati secara sempurna, barulah perkara tersebut dicarikan padanan dan kemiripannya dengan masalah serupa yang ada dalam bab fikih agar kemudian dapat didapatkan kaidah-kaidah, dalil-dalil beserta illat hukum yang berkaitan dengannya. Fase ini sangat membutuhkan ketelitian karena para ulama bisa saja berbeda dalam hal ini dan memasukkan suatu perkara ke dalam bab yang tidak sesuai sehingga memunculkan kesimpulan hukum yang keliru.

Fase selanjutnya adalah fase hukm, yaitu penentuan hukum terhadap masalah yang sedang dihadapi berbekal pada tashwir dan takyif yang benar dan melihat pada dalil-dalil hukum yang terkait baik dari al-Qur'an, Sunnah, Ijma', Qiyas atau dalil-dalil lainya.

Fase terakhir adalah fase ifta atau fase tanzil yaitu pengaplikasian hukum kepada kondisi riilyang dihadapi dengan mempertimbangkan konsekuensi (maalat) dari penyampaian hukum tersebut. 
Terkadang suatu hal yang pada dasarnya hukumnya adalah boleh bisa berpotensi memunculkan suatu mudarat maka hal tersebut bisa difatwakan tidak boleh, begitupun sebaliknyajika suatu hal pada dasarnya hukumnya adalah tidak boleh namun jika dilarang maka bisa menyusahkan bagi mustafti atau umat muslim secaraumum maka hal tersebutbisa difatwakan boleh ('Allam, 2020c).

Dalam fatwa terkait pelaksanaan shalat Jum'at ini,empat langkah fatwa ini dijalankan denga $\mathrm{n}$ baik Fase tashawwur terletak pada pemahaman mufti terhadap pertanyaan yang diajukan dan respon dari mufti dalam menjawab pertanyaan yang diajukan. Pertanyaan tersebut juga dilampirkan secara lengkap di dalam kompilasi fatwa sebelum penul isan jawaban fatwa agar pembaca dapat memahami konteks dari kemunculan fatwa tersebut. Halini berbeda misalkan dengan tata carapenulisan fatwadi Majelis Ulama Indonesiayang tidak secara langsung menuliskan pertanyaan dari mustafti namun hanya menuliskannya secara singkat pada bagian "menimbang".

Fase takyif terlihat pada pembahasan para mufti tersebut yang terfokus pada pembahasan mengenai syarat sah shalat Jum'at karena permasalahan yang dibahas sangat erat kaitannya dengan hal tersebut. Fase hukm terlihat pada penyampaian sejumlah aturan mengenai syarat sah shalat Jum'at dan penjelasan bahwa shalatyangtidak memenuhi syarat-syarat tersebut maka tidaklah sah. Sedangkan fase ifta terlihat pada keseluruhan jawaban dari mufti setelah mempertimbangkan berbagai hal yang berkaitan dengan permasalahan yang dihadapi. Dalam permasalahan ini tidak terlihat ada perubahan hukum dari fase hukm hingga fase ifta, hal itu karena hukum yang dijelaskan telah dilandasi oleh Ijma' hingga putusan hukumnya bersifat qath'i atau pastidan tidak menerima perubahan ataupun perbedaan pendapat.

Terkait dengan rujukan atau landasan dalam berfatwa, Dar al-Ifta berbeda dengan (misalkan) Majelis Tarjih Muhammadiyah atau Dewan Hisbah Persis di Indonesia yang dalam kajian fatwanya melakukan penelusuran langsung kepada nas al-Qur'an dan Hadis sejak awal. ${ }^{1}$ Dalam kajiannya Dar alIfta al-Mashriyyah memulai kajian dengan penelusuran terhadap pendapat dan penjelasan para ulama terlebih dahulu sebelum masuk ke dalam nas. Penelusuran tersebut dapat digam barkan dalam lingkaranlingkaran yangsemakin lanjut semakin meluas.

Dalam tahapannya, Dar al-Ifta al-Mashriyyah memulai dengan penelusuran terhadapliteraturyang berasal dari empat mazhab Sunni: Hanafi, Maliki, Syafi'i dan Hanbali, ini adalah lingkaran pertama yang menjadi rujukan utama dalam berfatwa. Dalam hal tidak didapatkan pembahasan darilingkara n tersebut, atau mencari penjelasan atau penguatan argumentasi yang lebih baik, maka Dar al-Ifta al-Mashriyyah menelusuri dengan lingkaran yang lebih luas dengan memasukkan literatur dari 4 mazhab lain selain Sunni, yaitu mazhab Imami, Zaidi, Ibadhi dan Zahiri.

Pada lingkaran ketiga, Dar al-Ifta al-Mashriyyah mengambil rujukan yang lebih luas lagi, yaitu pendapat sejumlah mujtahid di luar mazhab yang populer, seperti pendapat al-Layts b. Sa'ad (w. 175 H/791 M), 'Abd al-Rahman al-Awza'i (w. 157 H/774 M), Ibn Jarir al-Thabari (w. 310 H/923 M) dan sejumlah mujtahid lain yang jumlahnya sekitar 80 orang mujtahid.

Pada lingkaran keempat Dar al-Ifta al-Mashriyyah mengambil rujukan dari hasil ijtihad kolektif yang dilakukan oleh para ulama kontemporer di lembaga-lembaga kajian fikih Islam seperti Majma'alBuhutsal-Islamiyah lembaga riset keislaman yang berada di bawah naungan al-Azhar, Majma' al-Fiqh alIslami lembagariset fikih yang berada di bawah naungan Organisasi Konferensi Islam (OKI), dan Majma' al-Fiqh al-Islami yang berada di bawah naungan Liga Muslim Dunia, khususnya jika menghadapi suatu permasalahan yang benar-benar baru dan perlu untuk dipecahkan dengan segera.

1 (Anwar, 2018, hal. 19) (Abbas, 2016) 
Dar al-Ifta al-Mashriyyah terkadang juga melakukan penelusuran langsung terhadapnas al-Qur'an dan Hadis khususnya jika permasalahan tersebut tidak didapati penjelasannya di dalam literatur para ulama terdahuluatau penjelasannya ada namun konteksnya sudah tidak sesuai dengan konteks masa kini.

Dalam poin terakhir dari metode fatwanya dijelaskan bahwa jika terdapat perubahan fatwa atau perbedaan antara satu fatwa dengan fatwalain yang dirilis oleh Dar al-Ifta al-Mashriyyah dari masayang berbeda maka hal tersebut disebabkan karena adanya perbedaan empat hal yang memanglazimnya akan merubah hukum, yaitu perbedaan waktu, tempat, kondisi dan orang (Mu'tamad al-Fatwa fi Dar al-Ifta, 2011).

Jika fatwa-fatwa di atas dibandingkan, diketahui bahwa urutan dalam kutipan ini baru dilakukan sejak fatwa Jad al-Haqq yang menjadi mufti hingga tahun 1982. Fatwa-fatwa yang datang sebelumnya tidak banyak melakukan kutipan langsung dari para ulama sebagaimana yang telah dijelaskan, fatwafatwa tersebut langsung masuk ke dalam argumentasi baik dengan mengajukan dalil dari hadis, ijma' ataupun argumentasi lain. Berbeda dengan fatwa Jad al-Haqq ataupun Syauqi 'Allam yang didominasi oleh kutipan langsung pendapat para ulama. Maka, fatwa yang datang sebelum Jad al-Haqq relatif pendek, ringkas dan padat, berbeda dengan fatwa yang dirilis setelahnya yang relatif lebih panjang dan diisi dengan banyak kutipan langsung daripendapatpara ulama. Dari pembahasan ini diketahui bahwa terjadi perkembangan metodologi fatwa di Dar al-Ifta al-Mashriyyah antara sebelum Jad al-Haqq dan setelahnya.

\section{Argumentasi Dar al-Ifta al-Mashriyyah tentang Larangan Shalat Jum'at dalam Jaringan}

Dari limafatwa di atas, dapat kita simpulkan sejumlah argumentasi yang dijadikan landasan dalam pelarangan pelaksanaan shalat dalam jaringan dalam penjelasan berikut:

\section{Sunnah}

Sunnah yang digunakan sebagai landasan didalam fatwa-fatwatersebutada dalam bentuk sunnah qauliyyah ada juga sunnah fi'liyyah. Sunnah quliyyah yang dituliskan di dalam fatwa tersebut adalah penggalan hadis Rasulullah yang diriwayatkan oleh Bukhari (Al-Bukhari, n.d., hal. 166) dari Malik b. alHuwayrits bahwa Rasulullah bersabda:

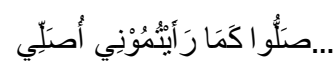

"Shalatlah sebagaimana kalihan melihatku shalat".

Hadis ini dikutip oleh Hasanayn Makhluf,Hasan Ma'mun, dan Khathir Muhammad. Hadis ini berisi tentang perintah untuk mengikuti Rasulullah dalam shalat, termasuk di dalamnya adalah tata cara pelaksanaan shalat Jum'at. Atas dasar hadis tersebut maka segala tata cara shalat harus mengikuti tata cara yang dilakukan oleh Rasulullah. Inilah yang kemudian dikenal dengan istilah sunnah fi'liyyah, yaitu perbuatan Rasulullah yang menjadilandasan hukum.

Hasanayn Makhluf,Hasan Ma'mun dan Khathir Muhammad menguatkan argumentasinya dengan hadis ini. Hasanayn Makhluf menyatakan, "Rasulullah tidak pernah shalat Jum'at kecuali secara berjamaah, dan beliau berkhutbah dua kali dengan duduk di antara keduanya sebagaimana yang diriwayatkan oleh Bukhari dan Muslim" (Makhluf, 2010). Hasan Ma'mun menyatakan, "Rasulullah melaksanakan khutbah dua kali dan memimpin shalat para jamaah" (Ma'mun, 2010). Hal yang serupa juga dinyatakan oleh Khathir Muhammad (Al-Syaykh, 2010).

Hadis diatas sebenarnya merupakan dalil yangumum dan tidak spesifik membahas mengenai tata cara pelaksanaan shalat jum'at, terlebih lagi jika konteks hadis tersebut dilihat secara utuh maka akan diketahui bahwa hadis itu adalah nasehat perpisahan dari Rasulullah kepada sejumlah sahabat mudayang 
sebelumnya nyantri di masjid Madinah untuk beberapa waktu. Namun karena hadis tersebut bermakna umum dan dapat masuk ke dalam setiap detail permasalahan di dalam bab shalat, maka hadis tersebut bisa dijadikan sebagai landasan bagi khutbah dan berjamaah sebagai syarat sah dari pela ksanaan shalat Jum'at.

\section{Ijma' $^{\prime}$}

Argumentasi Ijma' pertama adalah ijma' bahwa khutbah adalah syarat sah shalat Jum'at. Ijma' ini dikutip oleh Hasanayn Makhluf dari pernyataan Ibn Qudamah al-Maqdisi dalam bukunya al-Mughni yang menyatakan iniadalah ijma' dari imam empat (Abu Hanifah, Malik b. Anas, Muhammad b.Idrisal-Syafi'i, dan Ahmad b. Hanbal).(Makhluf, 2010) Fatwa yang lain juga menyebutkan hal ini meski tanpa menggunakan redaksi "ijma", seperti Hasan Ma'mun yang menggunakan istilah "la na'lam mukhalifan" (kami tidak mengetahui ada yang menentang hal ini) kecuali Imam Hasan al-Bashri yang menyatakan bahwa khutbah di dalam shalat Jum'at tidaklah wajib sebagaimana khutbah dalam shalat 'id, itu pun dikomentari oleh Hasan Ma'mun dengan 'tidak memiliki sanad (landasannya) dari Rasulullah ataupun umat Muslim setelahnya” (Ma'mun, 2010).

Ijma' yang kedua adalahijma' bahwa shalat Jum'at harus dilaksanakan secara berjamaah. Ijma' ini dikutip oleh Hasanayn Makhluf dari pernyataan Imam Nawawi dalam bukunya al-Majmu'. Hasanayn Makhluf menyatakan - setelah mengutip hadis di atas, “...Atas dasar itu telah terjadi Ijma' bahwa shalat Jum'at itu tidak sah kecuali dengan berjamaah dan dipimpin oleh salah seorang dari mereka sebagaimana yang dinyatakan oleh Imam Nawawi di dalam al-Majmu' (Makhluf, 2010).

Hal ini juga dikutip oleh Syauqi 'Allam di dalam fatwanya. Ia menyatakan, "Kata Jum’at berasal dari kata 'ijtima' - sebagaimana yang dinyatakan oleh al-Sughdial-Hanafi di dalam fatwanya. Atas dasar makna tersebut maka paraulama telahijma' mengenai keharusan terpenuhinya'jamaah' sebagai syaratsahnya shalat Jum'at." 'Allam juga mengutip pernyataan Imam al-Kasani dari mazhab Hanafi dalam bukunya Badai' al-Shanai' yang menyatakan, "La khilaf (tidak ada perbedaan pendapat) dalam hal pelaksanaan secara berjamaah adalah syarat dari pelaksanaan shal at Jum'at hingga tidak dihitung terjadi shal at Jum'at tanpa adajamaah."

Selain itu juga Syauqi 'Allam mengutip pernyataan dari sejumlah ulama lain dari mazhab Sunni seperti Imam Syihab al-Din al-Qarafi dari mazhab Maliki, Imam Haramayn al-Juwayni, Imam Ibn Hajar alHaitami, dan Imamal-Khathib al-Syarbini dari mazhab Syafi'i, Imamal-Mardawi dan Ibn 'Aqil dari mazhab Hanbali. Syauqi 'Allam kemudian menjelaskan bahwa meski para ulama memiliki perbedaan pendapat mengenai kriteria ijtima' yang menjadi syarat dalam pelaksanaan shalat Jum'at namun seluruhnya telah sepakat bahwa shalat Jum'atharus dilaksanakan dengan cara berjam aah ('Allam, 2020a).

Ijma' yang ketiga adal ah mengenai wajibnya pelaksanaan shalatjum'at di masjid. Hal ini disinggung oleh Jad al-Haqq dan disandarkan pada imam empat. Jad al-Haqq menyatakan, “...Shalat Jum’at dengan tata cara ini tidak sah di dalam syariat menurut kesepakatan para imam yang empat, karena mereka semua mensyaratkan pelaksanaannya harus dilakukan di masjid sebagai syarat sah pelaksanaan shalat Jum'at..."(Al-Haqq, 1979).

Ijma' pada dasarnya dapat dikatakan sebagai suatu dalil yang kuat, bahkan jika dibandingkan dengan sejumlah dalil yang digunakan oleh Dar al-Ifta al-Mashriyyah dalam perkara pelaksanaan shalat Jum'at ini ijma' adalah dalilyang paling kuat. Hal tersebut karena ijma' menjadikan suatu hukum menjadi bersifat qath'i atau pasti, bahkan tidak boleh dilanggar dan tidak boleh ada perbedaan pendapat di dalamnya, berbeda dengan hadis yang masih memiliki sisi zhanni baik dari sisi wurud ataupun dari sisi dilalah sehingga bisa memunculkan ragam tafsir dan perbedaan pendapat. 
Sifat qath'i dari hasil ijma' ini dinyatakan oleh Ali Jum'ah Muhammad Mufti Negara Mesir ke 19 (2003-2013) dalam al-Ijma' 'inda al-Ushuliyyin yang mengutip sejumlah pendapat ahli ushul fiqh seperti al-Syafi'i, al-Shayrafi, al-Syirazi, al-Khathib al-Baghdadi, Imam al-Haramayn al-Juwaini, Ibn Burhan, alGhazali, al-Dabusi dan al-Sarakhsi (Jum'ah, 2009, hal. 25-28). Bahkan jika argumentasi ijma' ini dibandingkan dengan argumentasi sunnah di atas, sunnah tersebut masih bersifat zhanni karena maknanya umum dan tidak secara spesifik membahas mengenai tata cara shalatjum' at sehingga adanya tiga ijma' dari para ulama ini mengikat perbedaan penafsiran yang mungkin terdapat dalam hadis tersebut hingga maknanya menjadi pasti.

\section{Kutipan ijtihad ulama}

Kutipan terhadap pernyataan para ulama banyak dilakukan oleh Jad al-Haq dan Syauqi 'Allam dalam fatwa mereka ketimbangtigafatwayang lain, bahkan dapat dikatakan bahwa Syauqi 'Allam dan Jad al-Haq di dalam fatwanya tidak menuliskan argumentasi selain dari kutipan terhadap pendapat para ulama ini, bahkan argumentasiijma' pun dikutip dariulama lain yang menyatakan adanyaijma' tersebut.

Pengutipan terhadap pendapat ulama sejatinya tidak hanya bersandar pada pendapat ulama tersebut namun juga kepada dalil dan argumentasi yangmenjadi landasan daripendapat tersebut. Karena pendapat-pendapat para ulama yang dikutip itu pada dasarnya merupakan hasil ijtihad yang kemunculannya melalui proses penelaahan terhadap sejumlah dalil-dalil yang berkaitan dengan hal yang sedang dibahas sehingga dapat dikatakan bahwa mengikuti pendapat mereka berarti sama dengan mengikuti dalil sebagaimana cara mereka memahaminya.

Di antara argumentasi yang dikutip adalah shalat Jum'at itu harus dilaksanakan di dalam masjid dan bukan di luar masjid, dan jika dilaksanakan (oleh sebagian orang) dari luar masjid maka syaratnya adalah adanya ketersambungan shaff dengan jamaah lain. Argumentasi ini dinyatakan oleh Syauqi 'Allam dengan mengutip pernyataan dari Imam al-Buhuti dari mazhab Hanbali yang menyatakan, "Jika makmum dapat melihat imam atau dari belakangnya, dan keduanya sama-sama berada di dalam masjid maka shalatnya tetap sah meski tidak adaketersambungan antara shaffsecara'urf, karena masjid itu dibangun untuk pelaksanaan shalat jamaah, maka siapapun yang berada di masjid maka ia berada di tempatjamaah. Lain hal dengan bagianluar masjid, wilayah itu tidak disediakan untuk jamaah di sana, maka disyaratkan adanya ketersambungan shaffdengan jamaah lain" ('Allam, 2020a).

Syauqi 'Allam juga mengutip ragam pendapat yang berbeda mengenai batasan maksimal jarak antara satu shaf dengan shaf lainnya sehingga shalat tersebut masih dianggap melaksanakan shalat berjamaah di satu tempatyang sama.

Argumentasi lain yang dikutip adalah bahwaimam dan makmum harusberada di satu tempatyang sama. Hal ini dikutip oleh Syauqi 'Allam dari Imam al-Kasani dalam Badai' al-Shanai' yang menyatakan, “...dan di antara (syarat sah)nya adalah menyatunya tem pat imam dan makmum." Hal yang sama juga dinyatakan oleh Ibn Hajar al-Haitami bahwa, "Jika syarat sah bermakmum itu cukup dengan mengetahui pergerakan imam saja (tanpa adanya persamaan tempat) maka perintah bergegas untuk pergi ke masjid ketika shalat Jum'at dan panggilan jamaah tidak berguna karena orang-orang bisa melakukannya di rumah mereka atau pasar mereka dengan imam yang berada di masjid, dan ini bertentangan dengan alQur'an dan Sunnah. Maka, harus ada syarat menyatunya tempat imam dan makmum karerna tujuan dari bermakmum dalam shalat itu adalah bersatunya sejumlah orang di satu tempat secara 'urf" ('Allam, 2020a).

Argumentasi yang dikutiplainnya adalah kewajiban hadir di masjid saat adanya khutbah dan tidak cukup jika hanya mendengar khutbah tanpa hadir di tempatitu. Hal in idikutip oleh Syauqi 'Allam darial- 
Kasani dalam Badai' al-Shanai'danjuga Ibn 'Abidin dalam Radd al-Muhtar 'ala al-Durral-Mukhtar. Syauqi 'Allam menyatakan,"Para ulama telah mensyaratkan al-hudhural-makani (hadir ditempat) saat khutbah Jum'at agar shalat Jum'atnya sah, bahkan mereka menjadikan hadir saja sebagai syarat namun tidak dengan mendengarkan, ini menunjukkan bahwa mencukupkan dengan mendengarkan khutbah tanpa hadir di tempatnya menjadikan shalatJum'atnya tidaksah ('Allam, 2020a).

\section{Argumentasi Pribadi}

Selain berfatwa menggunakan kutipan langsung dari sejumlah dalil di atas, terdapat juga argumentasi yang merupakan argumentasi pribadi yang tidak diperkuat dengan kutipan dari dalil ataupun ijtihad para ulama.

Argumentasi pribadiyang dinyatakan di dalam fatwa Dar al-Ifta al-Mashriyyah mengenai kasusini adalah argumentasi mengenai posisi khutbah di dalam shalatjum'atyangmerupakan pengganti dari dua rakaat shalat dzuhur. Argumentasi ini dinyatakan oleh Hasan Ma'mun dan Muhammad Khathir. Hasan Ma'mun yangmenyatakan, “...Khutbah Jum'at diadakan sebagai pengganti dua rakaat dari shalat dzuhur, maka ia adalah bagian yang tak terpisahkan dari shalat Jum'at" (Ma'mun, 2010). Muhammad Khathir di dalam fatwanya juga menyatakan, "...karena khutbah didirikan sebagai pengganti dua rakaat maka ia adalah bagian dari shalatjum'atatau minimal seperti bagian darinya (Al-Syaykh, 2010).

Pernyataan di atas memang tidak didasarkan atas kutipan terhadap dalil ataupun ijtihad para ulama, namun jika pernyataan tersebut ditelusuri lebih dalam maka sumber dari argumentasi tersebut dapat ditemukan, salah satunya ada di dalam al-Mushannaf karya Ibn Abi Syaybah dari Umar b. Khaththab bahwa ia berkata (AbiSyaybah, 2004, vol. 2),

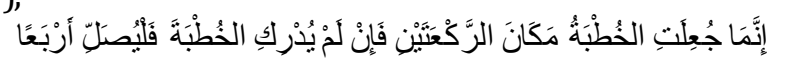

"Sesungguhnya diadakan khutbahitu (sebagai pengganti) dua rakaat, makajika ia tidak mendapati khutbah hendaklah iashal at empat rakaat".

Pernyataan ini adalah pernyataan Umar b. Khaththab yang tidak dinisbatkan kepada Rasulullah ataupun kepada masa Rasulullah, atas dasar ini dapatdikatakan bahwa pernyataan itu merupakan ijtihad pribadi Umarb. Khaththab dan bukan merupakan sebuah hadisbaik mauqufataupun marfu'.

\section{SIMPULAN}

Dapat disimpulkan bahwa Dar al-Ifta al-Mashriyyah menyatakan shalat Jum'at yang dilaksanakan dalam jaringan adalah tidak sah dan itu dinyatakan melalui lima fatwa: satu fatwa merespon mengenai shalat dalam jaringan melalui video call dan empat fatwa lainnya melalui radio. Argumentasi yang digunakan oleh Dar al-Ifta al-Mashriyyah dalam hal ini adalah Sunnah Fi'liyyah yang ditegaskan oleh Sunnah qauliyyah, Ijma', kutipan dari para ulama dan argumentasi pribadi yang sejatinya didasari oleh riwayat dari ulama salaf. Argumentasi terkuat yang diajukan di dalam masalah ini adalah ijma', karena suatu perkara yang telah dilandasi oleh ijma' tidak dapat dilanggar dan tidak menerima adanyaperbedaan pendapat, sehingga jika dibandingkan dengan argumentasi Wawan Gunawan Abdul Wahid dalam masalah ini-sebagaimana yang dijelaskan di bagian pendahuluan-maka argumentasi Dar al-Ifta alMashriyyah dalam fatwanyaini lebih kuat. Penelitian inijuga menemukan telah terjadi perubahan metode dalam perumusan fatwa di mana tiga fatwa pertama secara langsung menyebutkan hadis dan menjelaskan kandungan hadis tersebut sedangkan dua fatwa yang terakhir sama sekali tidak mengutip hadis secara langsung danlebih banyak di isi dengan kutipan dari para ulama dengan berbagai mazhabnya. 
Penelitianlanjutan yang dapat dilakukan adalah penelitian terhadap sejumlah fatwa dari lembaga fatwa darinegara-negara lain yang berkaitan dengan temayang dibahas mengingattema ini merupakan perkara baru dalam fikih (nazilah) dan banyaknya lembaga fatwa di dunia muslim. Penelitian lainnya adalah penelitian mengenai fatwa-fatwa lain dari lembaga fatwa Dar al-Ifta al-Mashriyyah mengingat minimnya penelitian tentang lembaga tersebut-khususnya di Indonesia-yang berbanding terbalik dengan fatwa yang telah dirilis oleh lembaga tersebut.

\section{DAFTARPUSTAKA}

'Allam, S. (2020a). Fatawa al-Nawazil: Waba Corona (Covid-19) (1 ed.). Dar al-Ifta al-Mashriyyah. 'Allam, S. (2020b). Shalat al-Jum'ah Khalf al-Tilfaz. Dar al-Ifta al-Mashriyyah. https://bit.ly/3sobfEZ 'Allam, S. (2020c). Ta'shil Fiqh al-Thawari'. Majallat Dar al-Ifta al-Mashriyyah, 12(43), 12-47. https://doi.org/10.21608/DFTAA.2020.126300

Abbas, R. (2016). Ijtihad Dewan Hisbah Persatuan Islam dalam Hukum Islam. Al-Daulah: Jurnal Hukum dan Perundangan Islam, 6(1), 214-236. http://jurnalfsh.uinsby.ac.id/index.php/aldaulah/article/view/112

Abi Syaybah, A. b. M. b. I. b. (2004). al-Mushannaf(1 ed.). Maktabah al-Rusy Nasyirun.

Al-Bukhari, M. I. (n.d.). al-Jami' al-Musnad al-Sahih al-Mukhtashar min Umur Rasulullah Shallallah 'Alayh wa Sallam wa Sunanih wa Ayyamih. al-Maknaz al-Islami.

Al-Haqq, J. al-H. 'Ali. (1979). Shalat al-Jum'ah Khalf al-Midzya'. Dar al-Ifta al-Mashriyyah. https://bit.ly/2LBPzEH

Al-Sudais, H. binti A. al-'Aziz. (2021). Shalat al-Jama'ah khalf al-Midzya' aw al-Tilfaz'inda al-Hajah wa al-Nawazil. Majallat Kulliyyah al-Syari'ah wa al-Qanun Jami'at al-Azhar Far' Asyuth, 33(1), 724-808. https://doi.org/10.21608/JFSU.2021.142531

Al-Syaykh, M. K. M. (2010). Hukm al-Shalat Wara'a al-Midzya'. In al-Fatawa al-Islamiyah min Dar alIfta al-Mashriyyah (1 ed., hal. 57-58). Dar al-Ifta al-Mashriyyah.

Anwar, S. (2018). Manhaj Tarjih Muhammadiyah (1 ed.). Majelis Tarjih dan Tajdid Pimpinan Pusat Muhammadiyah.

Arfa, F. A. (2010). Metodologi Penelitian Hukum Islam (W. Marpaung (Ed.); 1 ed.). Citapustaka Media Perintis.

Jum'ah, A. (2009). al-Ijma' 'inda al-Ushuliyyin (2 ed.). Dar al-Risalah.

Kenshanahan, A. (2021, Januari 8). Fenomena Salat Jumat Online di Sejumlah Negara Selama Pandemi Corona. Kumparan. https://kumparan.com/kumparannews/fenomena-salatjumat-online-di-sejumlah-negara-selama-pandemi-corona-1uvZD7EP1x5/full

Khairuldin, W. M. K. F. W., Hassan, S. A., Anas, W. N. I. W. N., Mokhtar, W. K. A. W., \& Embong, A. H. (2020). Al-Takyif Al-Fiqhi and its application in Islamic research methodology. Journal of Critical Reviews, 7(7), 462-467.https://doi.org/10.31838/jcr.07.07.80

Kurniawan, A. (2020). Hukum Shalat Jumat Online atau Live Streaming via Media Sosial. NU Online. https://islam.nu.or.id/post/read/119154/hukum-shalat-jumat-online-atau-livestreaming-via-media-sosial

Ma'mun, H. (2010). Sama' Khuthbah al-Jum'ah min al-Radiyu. In al-Fatawa al-Islamiyah min Dar alIfta al-Mashriyyah (1 ed., hal. 29-30). Dar al-Ifta al-Mashriyyah.

Makhluf, H. M. (2010). Shalat al-Jum'ah Khalf al-Midzya' Gayru Jaizah. In al-Fatawa al-Islamiyah min Dar al-Ifta al-Mashriyyah (1 ed., hal. 26). Dar al-Ifta al-Mashriyyah.

Mu'tamad al-Fatwa fi Dar al-Ifta. (2011). Dar al-Ifta al-Mashriyyah. https://bit.ly/2XJwBOW

Nuruddin, M. (2019). Ilmu Mantik (B. Irawan, Y. Arbi, \& P. T. Jaya (Ed.); 1 ed.). Keira.

Rusyana, A. Y., Supriyadi, D., Khosim, A., \& Nugroho, F. H. (2020). Fatwa Penyelenggaraan Ibadah di saat Pandemi Covid-19 di Indonesia dan Mesir. Perbandingan Mazhab dan Hukum, UIN Sunan Gunung Djati Bandung, January, 1-14. 


\section{Khazanah Hukum, Vol. 3 No. 2: 47 - 58}

Argumentasi Fatwa Dar Al-Ifta Al-Mashriyyah Tentang Shalat Jum'at Dalam Jaringan (Daring/Online) Fahmi Hasan Nugroho, Muhammad Syarif Hidayat

Siregar, E. N. N. (2021, Januari 8). Praktik Salat Jumat Online di Indonesia. Kumparan. https://kumparan.com/kumparannews/praktik-salat-jumat-online-di-indonesia1uvr0MIjMt3/full

Wahid, A. (2020). Pelaksanaan Shalat Berjamaah Di Masa Pandemi Covid-19 Perspektif Maqashid Syariah Serta Implikasinya Terhadap Ketahanan Ekonomi Keluarga. ANTARADHIN: Jurnal Ekonomi Syariah Kontemporer, 1(2), 123-136. http://jurnal.iailm.ac.id/index.php/antaradhin/article/view/277

Wahid, W. G. A. (2020). Sekali Lagi, Tidak Ada Masalah Shalat Jumat Secara Online. IB TImes. https://ibtimes.id/sekali-lagi-tidak-ada-masalah-shalat-jumat-secara-online/ 